\title{
Netrin-1: Just an axon-guidance factor?
}

\author{
L. Baioni • G. Basini • S. Bussolati • C. Cortimiglia • \\ F. Grasselli
}

Published online: 14 May 2010

(C) Springer Science+Business Media B.V. 2010

\begin{abstract}
Netrin-1 was first identified as a guidance factor in axon outgrowth during central nervous system development and was later shown to be involved in the morphogenesis of other organs. This study, thus, aimed to verify netrin-1 gene expression in swine antral follicles and to detect netrin-1 protein expression in follicular fluid. In addition, since netrin-1 is also a potential guidance factor for endothelial cells during angiogenesis, an essential event for follicular development, we attempted to verify its effects on swine aortic endothelial cells. Our results show that netrin-1 is present in follicular fluid and is physiologically expressed in both the thecal and granulosa layers from swine antral follicles. Furthermore, by means of an angiogenesis bioassay, we documented the inhibition of vascular neoformation by netrin-1. In conclusion, our results demonstrate that netrin-1 can be synthesized by swine follicular cells and secreted in the follicular fluid where it appears to exert regulatory effects on both follicular function and vascular development.
\end{abstract}

Keywords Angiogenesis $\cdot$ Netrin-1 $\cdot$ Ovary

\begin{tabular}{ll}
\multicolumn{2}{l}{ Abbreviations } \\
AOC & aortic endothelial cell \\
DAB & $3,3^{\prime}$ diaminobenzidine \\
FCS & fetal calf serum \\
MC & microcarriers \\
PBS & phosphate buffered saline \\
SDS-PAGE & sodium dodecyl sulphate - polyacrylamide gel electrophoresis \\
TBS & tris-buffered saline \\
TTBS & tris-buffered saline plus tween \\
UNC5B & uncoordinated 5B \\
PCR & polymerase chain reaction
\end{tabular}

L. Baioni $\cdot$ G. Basini $(\bowtie) \cdot$ S. Bussolati $\cdot$ C. Cortimiglia $\cdot$ F. Grasselli

Dipartimento di Produzioni Animali, Biotecnologie Veterinarie, Qualità e Sicurezza degli Alimenti, Facoltà di Medicina Veterinaria, Università degli Studi di Parma, Via del Taglio 10, 43100 Parma, Italy e-mail: basini@unipr.it 


\section{Introduction}

In 1994, Kennedy and collaborators discovered netrin-1 (Kennedy et al. 1994), a factor that guides axon pathfinding during the development of the central nervous system. Netrin-1 involvement in the morphogenesis of other organs (mammary gland, pancreas, and lung) has been documented previously, and its expression has been demonstrated in the heart, liver, kidney, intestine, stomach, thymus, and testicles (Engelkamp 2002). At present, the only experimental evidence of the protein within the ovary is related to swine granulosa cells (Maeda et al. 2008). Therefore, the first aim of this study was to verify netrin-1 expression in swine ovarian follicles greater than $5 \mathrm{~mm}$, in both the theca and granulosa layer. In addition, we tried to verify its presence in the follicular fluid by Western blot. Recent studies show that netrin-1 is able to drive pathfinding of not only neurons, but also of endothelial cells during blood vessel development (Wilson et al. 2006). In particular, Lu and co-workers (Lu et al. 2004) have shown that netrin-1 mediates repulsive guidance in the growth of the vascular network through its binding to the UNC5B receptor. In contrast, Park and colleagues (Park et al. 2004) report a promoter effect on both migration and proliferation. Therefore, using an angiogenesis bioassay (Basini et al. 2008), we examined the effects of netrin-1 on the development of new blood vessels.

\section{Materials and methods}

Swine ovaries were obtained from a slaughterhouse, and antral follicles greater than $5 \mathrm{~mm}$ were isolated. Granulosa cells were separated from the thecal membrane, and RNA was extracted and reverse-transcribed. The cDNA obtained was subjected to PCR using the primers pACTIN sense (5'-GAGACCTTCAACACGCCG-3') and antisense (5'-GGAAGGTGGA CAGCGAGG-3'), with an expected product size of $685 \mathrm{bp}$; and netrin-1 forward (5'-GACG ACGACGAGGAGAACTC-3') and reverse (5'-GGGTGAGCTCAATCACAGTT-3'), which amplify a region of $449 \mathrm{bp}$. The amplified products obtained were subjected to electrophoresis in a $1.5 \%$ agarose gel stained with Gel Red dye (Biotium, Hayward, CA). Digital images were captured by a Power Shot A610 (Canon Italy SpA, Milan). Follicular fluid, collected by aspiration, was subjected to SDS-PAGE and subsequently blotted onto a ProBlott membrane. After transfer, the membrane was incubated in a solution of 5\% skim milk and TBS for 1 hour. After three washes in TTBS, the membrane was incubated with an anti-netrin-1 polyclonal antibody (Santa Cruz Biotechnology, Santa Cruz, CA). For immune complex detection, we used a universal biotinylated secondary antibody (LSAB ${ }^{\circledR}+$ System-HRP, Dako Cytomation, Carpinteria, CA) in combination with streptavidin-peroxidase and DAB as chromogen substrate.

The in vitro angiogenesis bioassay was performed by incubating $12.5 \mathrm{mg} \mathrm{MC}$ with $1.5 \mathrm{~mL}$ sterile PBS for 3 hours at $37^{\circ} \mathrm{C}$. After two washes, the $\mathrm{MC}$ were put in a flask containing AOC $\left(5 \times 10^{5}\right)$ at the 13 th passage, in $5 \mathrm{~mL} \mathrm{M} 199$ containing $2 \%$ FCS. The flask was incubated overnight at $37^{\circ} \mathrm{C}$ to let the AOC coat the MC. For fibrin gel preparation, the AOC-coated MC $(20 \mu \mathrm{L})$ were placed in 12-well plates containing a solution of fibrinogen

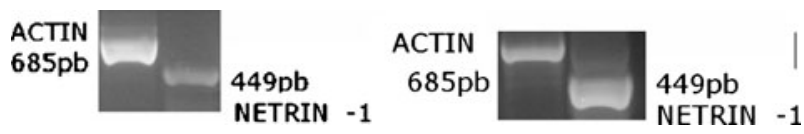

Fig. 1 Netrin-1 expression (and control actin expression) in granulosa cells (left) and theca cells (right) from large follicles 
Fig. 2 The ProBlott membrane shows a band of approximately $70 \mathrm{kDa}$, identifiable as netrin-1

$(1 \mathrm{mg} / \mathrm{mL}, \mathrm{pH} 7.6)$ and thrombin $(5 \mathrm{U} / \mathrm{mL})$. The plates were incubated for $30 \mathrm{~min}$ at $37^{\circ} \mathrm{C}$ to promote fibrin polymerization. Subsequently, $1 \mathrm{~mL}$ M199 was added to each well. After a change of medium, fibrin gels were treated with $100 \mathrm{ng} / \mathrm{mL}$ netrin-1 (kindly provided by Prof. Linsday Hink, University of California, Santa Cruz, CA) and incubated for 48 hours at $37^{\circ} \mathrm{C}$ in $5 \% \mathrm{CO}_{2}$. Photographic images were acquired after incubation to determine the area of vascular development. AOC proliferation in the fibrin gel was quantified using Scion Image 4.02 (Scion Corporation, Frederick, MA, http://rsb.info.nih.gov/nih-image/), which calculates the area occupied by endothelial cells expressed as the number of pixels. Statistical differences were calculated by ANOVA using Statgraphics software (STC Inc., Rockville, MD). When statistically significant differences were found $(p<0.05)$, means were submitted to the Scheffè's $F$ test for multiple comparisons.

\section{Results}

Netrin-1 gene expression was detected in both theca and granulosa cells isolated from large antral follicles (Fig. 1). Immunoblotting revealed the presence of netrin-1 in follicular fluid (Fig. 2).

Netrin-1 treatment produced a significant inhibition $(p<0.05)$ of angiogenesis in the area covered by endothelial cells on the fibrin gel (Fig. 3).

\section{Discussion}

Our results show that netrin-1 is present in follicular fluid and is physiologically expressed in both theca and granulosa cells of swine antral follicles larger than $5 \mathrm{~mm}$, suggesting its involvement in regulating follicular function. Netrin-1 appears to be primarily expressed in regions of tissue remodelling rather than in quiescent tissue (Strizzi et al. 2008). Interestingly, the ovarian follicle is a typical site of differentiation and reorganization

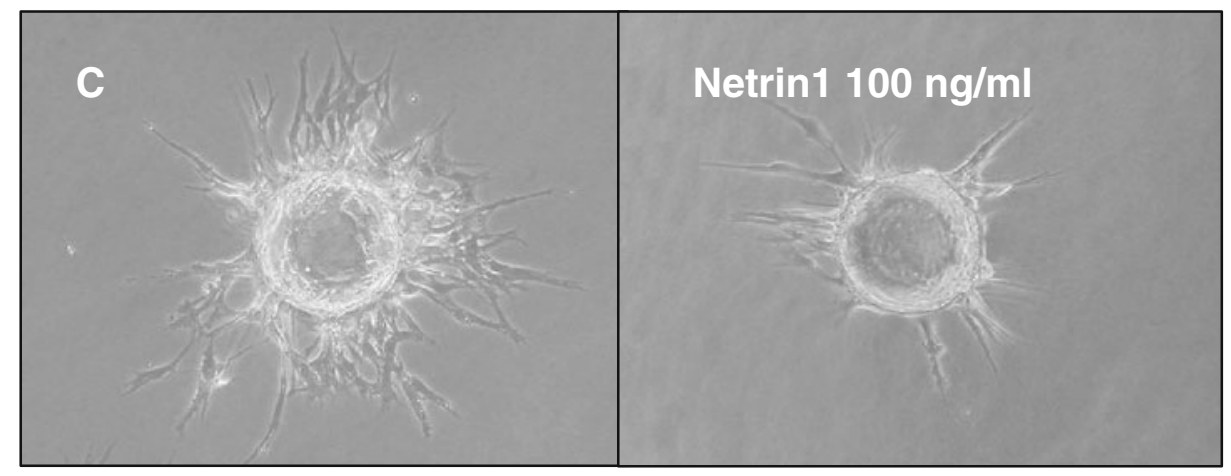

Fig. 3 Phase-contrast micrographs showing the effects of $100 \mathrm{ng} / \mathrm{mL}$ netrin-1 on AOC growth after 48 hours; C: control (no netrin-1) 
events, leading to the evolution of both its structure and the thecal vascular system. Therefore, netrin-1 could be actively involved in driving such dynamic events. Based on our data, we hypothesize that netrin-1 can be synthesized locally and could contribute both to the organization of follicle cells and to the regulation of blood network development, an essential event during follicular maturation. Specifically, using an angiogenesis bioassay, we documented the inhibition of vascular formation by netrin-1. This finding indicates that netrin-1 is an anti-angiogenic factor. Consistent with the data obtained in the nervous system where netrin-1 exerts opposing effects that depend on the type of receptor involved, previous studies documented that this protein can either inhibit or promote angiogenesis. In particular, Yang and colleagues (2007) showed that netrin-1 might act as a pro- or antiangiogenic factor, depending on its concentration and the type of receptor expressed by endothelial cells. In conclusion, this protein, which is known as an axon-guidance factor, can be synthesized by swine follicular cells and secreted into the follicular fluid where it can exert regulatory effects on neovascularization.

Acknowledgements This work was supported by MIUR-PRIN and FIL grants.

\section{References}

Basini G, Bussolati S, Santini SE, Bianchi F, Careri M, Mangia A, Musci M, Grasselli F (2008) Hydroxyestrogens inhibit angiogenesis in swine ovarian follicles. Endocrinology 199:127-135

Engelkamp D (2002) Cloning of three mouse Unc5 genes and their expression patterns at mid-gestation. Mech Dev 118:191-197

Kennedy TE, Serafini T, de la Torre JR, Tessier-Lavigne M (1994) Netrins are diffusible chemotropic factors for commissural axons in the embryonic spinal cord. Cell 78:425-435

Lu X, Le Noble F, Yuan L, Jiang Q, De Lafarge B, Sugiyama D, Bréant C, Claes F, De Smet F, Thomas JL, Autiero M, Carmeliet P, Tessier-Lavigne M, Eichmann A (2004) The netrin receptor UNC5B mediates guidance events controlling morphogenesis of the vascular system. Nature 432:179-186

Maeda A, Matsuda F, Goto Y, Cheng Y, Gonda H, Inoue N, Nakagawa S, Manabe N (2008) Molecular cloning of a porcine (Sus scrofa) apoptosis inhibitory ligand, netrin-1, and its receptor, p53RDL1. J Reprod Dev 54:275-280

Park KW, Crouse D, Lee M, Karnik SK, Sorensen LK, Murphy KJ, Kuo CJ, Li DY (2004) The axonal attractant netrin-1 is an angiogenic factor. Proc Natl Acad Sci USA 101:16210-16215

Strizzi L, Postovit LM, Margaryan NV, Seftor EA, Abbott DE, Seftor RE, Salomon DS, Hendrix MJ (2008) Emerging roles of nodal and Cripto-1: From embryogenesis to breast cancer progression. Breast Dis 29:91-103

Wilson BD, Ii M, Won Park K, Suli A, Sorensen LK, Larrieu-Lahargue F, Urness LD, Suh W, Asai J, Kock GAH, Thorne T, Silver M, Thomas KR, Chien C, Losordo DW, Li DY (2006) Netrins promote developmental and therapeutic angiogenesis. Science 313:640-644

Yang Y, Zou L, Wang Y, Xu KS, Zhang JX, Zhang JH (2007) Axon guidance cue Netrin-1 has dual function in angiogenesis. Cancer Biol Ther 6:743-748 